\title{
中空螺子を使った経皮的膝蓋骨骨折治療法
}

\author{
新小倉病院 \\ 目貫 邦 隆 \\ 宮崎病院 \\ 前田病院 \\ 伊 藤 謙 三

\section{Percutaneous Cannulated Screw Fixation for Patellar Fractures} \\ Kunitaka Menuki \\ Department of Orhtopaedic Surgery, Shinkokura Hospital \\ Shinichi Nakamitsu, and Ken Miyazaki \\ Department of Orhtopaedic Surgery, Miyazaki Hospital \\ Kenzou Itou \\ Department of Orhtopaedic Surgery, Maeda Hospital
}

中 光 紳 一・宮 崎健

\begin{abstract}
About the medical treatment of patella fracture, knee joint movement from an early stage is needed. We pay our attention to the dynamic intensity of Cannulated Screws, and perform Percutaneous Cannulated Screw Fixation to patella fractures. We examined results to 11 cases. All the men can sit up straight in about five weeks of averages.

There was no obstacle of the sharp pain and the skin damage by screws. We think that there is little surgical stress and it has sufficient fixed power. We consider this method to be the method of obtaining a movable region at an early stage.
\end{abstract}

Key words : Patella fracture（膝蓋骨骨折), canulated screw（中空螺子), perucutaneous（経皮的）

抄録

【目的】著者らは螺子の強い曲げ強度と引き抜き強度 に着目して，軽度な転位ある症例に対して，中空螺子 のみを用いた経皮的固定術を行っている．今回の 11 症例に対して成績を検討する。【手術方法】膝関節を 軽度屈曲位にして，レントゲン透視下に膝蓋骨末梢か らガイドワイヤーを中枢に向けて刺入する. 小切開後, 末梢の骨皮質をドリリングする．螺子は必ず中枢の骨 皮質を越えて挿入している。【結果】腓骨神経麻疸を 起こした一例を除き, 全例平均約 5 週で正座可能となっ
た、いずれ屯螺子による疼痛や皮膚の障害はなかった。 【考察】経皮的な中空螺子固定は手術侵襲が少なく, 十分な固定力が得られると考える。また，軟部組織に 対する刺激が少なく早期に正座が期待できる方法と考 える.

\section{はじめに}

膝蓋骨骨折では, 膝伸展力の低下と膝関節可動域の 損失を防ぐ目的から, 強固な内固定と早期からの可動 域訓練が望ましい。

筆者らは軽度転位ある症例に対して, 中空螺子のみ 
を用いて経皮的骨接合術を行い良い結果を得たので報 告する.

\section{I . 症例}

男性 1 例, 女性 11 例で, 年齢は 40 歳から 83 歳, 平均年齢は 67.1 歳であった。

すべて，転倒による膝頭を打撲した閉鎖骨折であり， 単純レントゲン写真による分類は, 横骨折が 8 例・綐 骨折 2 例・粉砕骨折 1 例であった。

\section{II. 方法}

麻酔は腰椎麻酔で行い, ターニケットは使用しなかっ た.

まず，関節穿刺にて血腫を除去後，膝関節を軽度屈 曲位にして, 膝蓋腱を除けて膝蓋骨下端からレントゲ ン透視下にガイドワイヤーを末梢から中枢に刺入する. 側面像でもガイドワイヤーの位置を確認した後, レン トゲン透視下に螺子の長さを計測する.

小皮切を加えた後に, 手前の骨皮質をドリリング後, 直径 $4.0 \mathrm{~mm}$ の中空螺子をラグスクリューの原則に倣っ て，必ず中枢側の骨皮質を越えて挿入する．レントゲ ン透視下に骨折部の整復を確認するとともに, 膝を屈 曲・伸展させて骨折部が安定していることを確かめる.

後療法は, クリティカルパスにそって行った。手術 翌日から, 膝装具を装着し歩行を許可する. 術後 1 週 から CPM に上る可動域訓練を開始し, 術後 2 週から 自動的可動域訓練を開始する. 膝装具は, 歩行時の膝 崩れが無いことを確認後, 適時除去する.

\section{III. 結 果}

術前から正座できなかった症例と神経麻痺をおこし た症例とを除き, 正座獲得時期は, 最短 3.5 週から最 長 7 週で平均 5 週であった。リハビリ中の螺子による 疼痛や皮膚障害は無く, また骨折部の離開や螺子の脱 転を認めた症例は無かった。

\section{IV. 代 表 症 例}

症例: 67 才男

仕事中階段を踏み外し左膝を強打して受傷した。直 後から膝部の疼痛のため歩行困難となり, 当科受診と なった。初診時の単純レントゲン写真では, 滕蓋骨下 極の横骨折, 及び膝蓋骨外側よりに綐骨折を認めた。 いずれも， $4 \mathrm{~mm}$ の骨折部の離開を認めた。CT では,
横断像にて $2 \mathrm{~mm}$ の関節面の不適合を認めた。また, 螺子刺入部位の骨皮質の損傷が無いことを確認した。

入院翌日, 腰椎麻酔下に中空螺子を用いた経皮的骨 接合術を施行した。手術時間は 20 分で，出血量は極 少量であった。術後レントゲン写真では, 骨折部の離 開は, 螺子固定により横骨折抢よび縦骨折ともに, 術 前 $4 \mathrm{~mm}$ から術後 $2 \mathrm{~mm}$ 之改善した。また関節面の 不適合性屯術前 $2 \mathrm{~mm}$ 加ら術後ほぼ $0 \mathrm{~mm}$ と改善を 認めた。

\section{V. 考 察}

骨片転位の少ない膝蓋骨骨折の治療法は保存的治療 が一般的であるが， Bostrom ${ }^{11}$ は2 289 例を保存的に 加療し, 約 4 割に疼痛が存在し, $12 \%$ に可動域制限が 残存したと述べている. 横山 ${ }^{6)}$ は転位の少ない症例に ついて，保存療法で良好な結果を得たので述べている が, 疼痛は 57 例中約半数, 可動域制限は $1 / 3$, 正座 不可は $1 / 3$ に存在したと述べている．福沢ら ${ }^{3)}$ 6転 位の少ない骨折は保存療法で良いと述べているが，48 例中約半数に疼痛が残り, $1 / 3$ に $1 \mathrm{~cm}$ 以上の大腿周 径差が存在している。.また, 運動制限及び筋萎縮は何 れも固定期間が 4 週以上と比較的な症例に多いと報告 している。 このことからも早期に可動域訓練（CPM） を開始し，拘縮の予防及び関節軟骨の修復を促す必要 があると考える。

膝蓋骨骨折の固定方法は様々な方法が提唱されてい るが、これらは鋼線による締結か螺子による骨片間固 定か，またはそれらを組み合わせたものであった。 Perry ${ }^{21}$ は引き寄せ締結や螺子固定後にさらに鋼線 やケーブルを使って固定支持性をます方法を行ってい るが，14 例中の 6 例において鋼線を疼痛のために抜 去している，このように，術後，鋼線やケーブルが皮 膚の刺激となって正座までの屈曲訓練を遅らせ, 歩行 時の伸展筋力を傷害することはよく経験し, 文献上で も高い頻度で報告されている，そのため, 強固な固定 力かつ機械的刺激の少ない固定材料による方法が望ま れる.

膝蓋骨には, 屈曲時では膝蓋骨周囲の張力から膝蓋 大腿関節を介して曲げ方向のストレスが加わる。一方 伸展時には, 大腿四頭筋張力は膝蓋骨に上下方向の毫 引力として作用する。したがって, 膝蓋骨骨折の固定 方法は屈曲時の曲げ強度と伸展時の引き抜き強度が一 定の閾値以上にあることが必要条件である。 
Carpenterらうは屍体をあちいてバイオメカニカルな 分析を行った．彼らはKワイヤーを用いた引き寄せ締 結法で固定した膝蓋骨が 45 度膝屈曲位で平均 395 Newton まで耐えられたのに対して，螺子 2 本による 固定法では 554 Newton の強度を示したことを挙げて， 螺子が引き寄せ締結法より有為に優っていると主張し ている．また，伸展時の骨片離開を計測したテストで も螺子は引き寄せ締結法に優ると報告されている ${ }^{4)}$.

著者らは，この中空螺子の強い 3 点曲げ強度と引き 抜き強度に着目して，本法を行ってきたが，これまで 固定性による問題は経験しておらず，症例を選べば十 分な固定性を得ることが出来ると考えている.

\section{VI. ま と め}

著者らは軽度転位ある膝蓋骨骨折に対して中空螺子 のみを用いた経皮的骨接合術を行った，本法は，小侵 襲で手技が容易な方法であり，螺子による機械的刺激 屯少なく, 創部痛による後療法の障害は少ないもので あった。

本法は治療期間の短縮および早期に正座を期待でき
る最小手術手技の考え方に沿った良い方法と考える.

\section{参 考 文 献}

1) Bostrom, A. Fracture of the patella. Acta Orthop. Scand. [Supple.], $143: 5,1972$.

2) Clayton R. Perry, John A. McCarthy, Christopher C. Kain, and Richard L. Pearson : Patellar Fixation Protected with a Load-Sharing Cable: A Mechanical and Clinical Study, J. Orthop. Trauma, Vol,2 No3 : 234-240, 1988.

3) 福沢玄英：膝蓋骨骨折の治療。災害外科, $13: 622-628$, 1970.

4) Greg A. Brown, Tracey McCarthy, Craig A. Bourgeault, and Dennis J. Callahan : Mechanical Performance of Standard and Cannulated 4.0-mm Cancellous Bone Screws, J. Orthopaedic Research, Vol. 18, No.2 : 307-312, 2000

5) James E Carpenter, Roberta Kasman, and Larry S. Matthews : Fractures of Patella, J. Bone and Joint Surg., vol.75-A, No.10 : 1550-1561, 1993.

6) 横山良治：神戸大学整形外科における膝蓋骨骨折治療 成績について。整形外科, 20：734-739，1969. 